\title{
Recriminations inflame UK research debate
}

\section{David Adam, London}

After a national tour of every university staff room in the country, the debate over Britain's Research Assessment Exercise (RAE) finally rolled into the House of Commons last week, amid acrimony, namecalling and threats of legal action.

Introduced in 1986, the assessment - an exhaustive audit of university research carried out every few years and linked directly to funding - is widely credited with raising the quality of British science, and has attracted interest from governments around the world. But it has not been without controversy, most recently when funds could not be

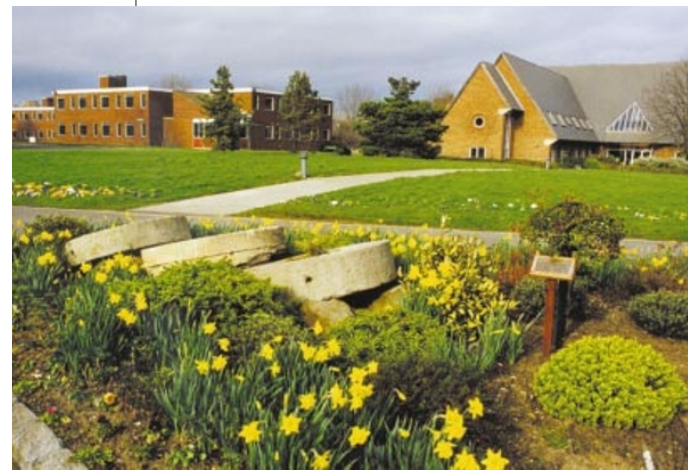

Environmental scientists at Cranfield University and elsewhere feel left out of assessment panels. found to reward record increases in RAE grades awarded by the 2001 exercise (see Nature 414, 834;2001).

The process has faced even closer scrutiny and much scepticism at home since the results of the latest audit were announced in December last year. On 26 June, the Higher Education Funding Council for England (HEFCE), the body that operates the RAE, announced a major review to decide whether and how the exercise should be repeated. "We want to get people to look forward to what will happen in the future," says Philip Walker, a spokesperson for the council.

But in the Commons debate on 27 June, Ian Gibson, Labour Member of Parliament for Norwich North and chair of the House of Commons Science and Technology Select Committee, said that HEFCE officials had been "arrogant and dismissive" about criticism of the RAE. And a group representing the heads of environmental-science departments wrote to the council on 28 June demanding a review of the way their subject is assessed.

The environmental scientists say that a statistical analysis of the latest audit for their departments reveals irregularities. They say that their departments scored, on average, two grades lower than departments in other disciplines, and complain that there were too few specialists from their subject on the assessing panel. With no appeal mechanism open to them, some departments have considered asking a court to overturn the results.

"Possible legal action is being discussed but it's expensive and I don't think any university would embark on a legal process on their own," says William Stephens, head of the Institute of Water and the Environment at Cranfield University in Bedfordshire.

Last week the HEFCE also published its response to a highly critical report released by Gibson's committee in April. The committee labelled the assessment a "damaging distraction" and said that it distorts research practices, ruins careers and hastens departmental closures. The HEFCE retorted that there is no hard evidence to support the criticisms. Gibson responded that the council is "out of touch with the community it serves".

Several researchers contacted by Nature side with Gibson. One physicist at a leading UK university even claims that scientists' names have been inappropriately added to research papers to boost their departments' scores in the audit.

But HEFCE officials stress that the RAE has achieved its goals, adding that critics are too quick to blame the exercise when unpopular decisions are taken for other reasons. "Disentangling the effects of the RAE from other pressures on the sector is not as straightforward as it may appear," says Bahram Bekhradnia, the HEFCE's director of policy.

\section{Angry scientists march on Moscow in budget protest}

\section{Bryon MacWilliams, Moscow}

Dozens of scientists trekked more than 130 kilometres over three days, through heavy wind and rain, in a bid to hold Russian President Vladimir Putin to a promise on research spending. It didn't work.

In March, Putin pledged to budget 49.5 billion rubles (US\$1.5 billion) for scientific research in the 2003 fiscal year, which begins in January. But last month, he released a budget proposal that allocates just 35 billion rubles to science.

The long march from Pushchino - a city south of Moscow that houses several large biology laboratories run by the Russian Academy of Sciences - was called by trade unions in protest against scientists' living conditions.

But government officials declined to meet with union officials and said that the revised budget figures would stand. And the march, which began with 30 protesters in the expectation of gathering support along the way, attracted only about 100 scientists. That allowed a closing rally in Moscow on 27 June to be dominated by flag-waving members of

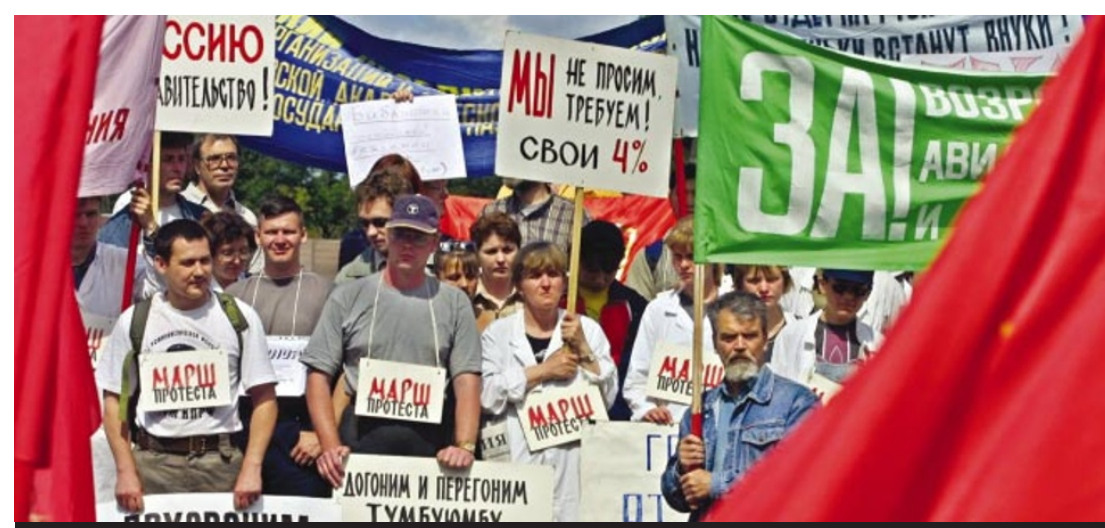

Tired and flagging: beleaguered researchers hold a rally to mark the end of their marathon march.

the opposition Communist Party, who easily outnumbered the marchers.

The latest budget proposal comfortably exceeds this year's annual science spending of 21.7 billion rubles. But union leaders called for the march after meeting with ministers and failing to win promises of more overall spending, better housing allowances for young scientists and increased grants for graduate students.

"Government bureaucrats are sabotaging the decision of our president to support the sciences," claims Valery Sobolev, chairman of the trade unions of the Russian Academy of Sciences. Union officials say that low wages are forcing researchers to earn money from commercial sources, damaging basic scientific research. 